\title{
Income and Employment Generation under Optimum Combination of Different Enterprises in Sugarcane Based Farming System for Small Category of Farms in District Meerut of Uttar Pradesh, India
}

\author{
Subhash Kumar Jawla ${ }^{1 *}$, Babu Singh', Teshu Kumar ${ }^{2}$ and Rahul Katiyar ${ }^{1}$ \\ ${ }^{1}$ Chandra Shekhar Azad Universities of Agriculture and Technology, Kanpur - 208001, Uttar \\ Pradesh, India \\ ${ }^{2}$ Lovely professional University, Jalandhar, Punjab, India \\ *Corresponding author
}

\section{A B S T R A C T}

\section{Keywords}

Farming system, Optimization, LP model, Livestock, Land allocation, Employment generation.

Article Info

Accepted:

08 June 2018

Available Online: 10 July 2018
The present study was conducted during the year 2013-14 in District Meerut of Uttar Pradesh to know the possibilities of optimum combination of different enterprises for the enhancement of the farms income and employment of small category of farms household's. Multistages tratified random sampling design was used to collect the primary data from; a sample of 32 respondents was selected on the basis of probability proportion to size of holdings. A linear programming (LP) model was used to find out the optimal farm plan for optimum land allocation for maximization of net returns and to generate employment from, small category of farms. In the study area, Small farms linear programming model resulted that increase in return which was 33.72 per cent higher than the existing farm plan and labour man days 69.59 per cent higher compare to the existing farm plan.

\section{Introduction}

Agriculture continues to be the backbone of Indian economy. It may be noted that Indian agriculture is the home of small and marginal farmers $(80 \%)$ The structural reforms and stabilization policies introduced in India in 1991 initially focused on industry, tax reforms, foreign trade and investment, banking and capital markets. The economic reforms did not include any specific package specifically designed for agriculture. We have problems of poverty, unemployment, inequalities in access to health and education and poor performance of agriculture sector. One of the excluded sector during the reform period was agriculture which showed low growth and experienced more farmers' suicides. There are serious concerns on the performance of agriculture sector in the country. Especially for small and marginal farmers who constitute more than 80 Per cent of the farming community. The crop and cropping system based research needs to be 
conducted in a holistic manner for the generating suitable management of available resources in an optimum manner by small farmer. Compared to many other crops grown, sugarcane is a highly versatile plant which is successfully grown as a cash crop under a wide range of conditions in Meerut. Soil texture varying from light sands to heavy clay and under $\mathrm{pH}$ ranging from 4 to 7 , and it also shows remarkable resistance to drought. Therefore the farming systems approach is a valuable tool for addressing the problems of sustainable economic growth for farming communities in India. Farming System is a complex inter-related matrix of soil, plants, animals, implements, power, labour, capital and other inputs controlled in parts by farming families and influenced to varying degrees by political, economic, institutional and social forces that operate at many levels. Agriculture production and livestock production are intrinsically linked, one be dependent on the other, and both crucial for overall food security. The role of small farms in development and poverty reduction is well recognized (Lipton, 2006). The global experience of growth and poverty reduction shows that GDP growth originating in agriculture is at least twice as effective in reducing poverty as GDP growth originating outside agriculture (WDR, 2008). Small holdings play important role in raising agricultural development and poverty reduction.

The objective of this paper is to examine the role and challenges of small holding agriculture in achieving agricultural growth, food security and livelihoods in India. Small holdings also face new challenges on integration of value chains, liberalization and globalization effects, market volatility and other risks and vulnerability, adaptation of climate change etc. (Thapa and Gaiha, 2011). One of the paradoxes of the Indian economy is that the decline in the share of agricultural workers in total workers has been slower than the decline in the share of agriculture in the GDP. Thus, the small holding character of Indian agriculture is much more prominent today than even before. The average size of holdings in India declined from 2.3 ha. in 1970-71 to 1.33 ha. in 2000-01.

\section{Materials and Methods}

District Meerut was purposively selected for present investigation. Being homogeneous of all the Blocks, two blocks were selected randomly i.e. Hastinapur and Sardhana. Three villages were selected randomly from each block. List of all the farmers of the selected villages was prepared according to their land holding size. A sample of 32 respondent having area upto 1-2 hectare were selected on the basis of probability proportional to their total numbers. Required primary data on crops, livestock and other allied enterprises was collected by personnel interviewed method and secondary data was also collected from various published sources. CACP cost concept and Linear programming is a systematic and accurate method of determining mathematically the optimum combination of enterprises or inputs so as to maximize the income or minimize the cost within the limits of available resources.

Programming approach of the following form was used use to optimize the return from Sugarcane Based Farming System.

\section{Objective function -I (Maximization of income)}

Where,

$$
\operatorname{Maximize~} \mathrm{Z}=\sum_{\mathrm{j}=1}^{\mathrm{n}} \mathrm{CjXj}
$$

$\mathrm{Z}=$ Net returns (income) variable cost in rupees

$\mathrm{Cj}=$ Net return over variable costs per unit of 
$\mathrm{j}$-th activity in rupees

$\mathrm{Xj}=$ The level of $\mathrm{j}$-th activity,

\section{Subject to constraints}

$\sum_{j=1}^{N}$ aijxij $\quad \leq \quad$ bi

Non-negative decision variable

$\mathrm{Xij} \geq 0$

Where:

aij= amount of $i-$ th resource required for the $j-$ th activity,

bi $=$ total available quantity of $i$-th resources.

$\mathrm{i}=1,2,3, \ldots \ldots \ldots \ldots \ldots \ldots \ldots \ldots \ldots \ldots \ldots$, resources)

$\mathrm{j}=1,2,3, \ldots \ldots \ldots \ldots \ldots \ldots \ldots . . . \mathrm{n}$, activities)

The farmer must decide how many hectares that should be allocated to each activity. So the decisions are:

$\mathrm{X} 1=$ hectares allocated for paddy production .

$\mathrm{X} 2=$ hectares allocated for Jawar production.

$\mathrm{X} 3=$ hectares allocated for sugarcane production.

$\mathrm{X} 4=$ hectares allocated for wheat production.

$\mathrm{X} 5=$ hectares allocated for potato production.

$\mathrm{X} 6=$ hectares allocated for mustard production.

$\mathrm{X} 7=$ hectares allocated for oat production.

$\mathrm{X} 8=$ number allocated for buffalo rearing.

$\mathrm{X} 9=$ number allocated for cow rearing.

\section{Results and Discussion}

\section{Optimum farm plan for small farms}

The linear programming formulation for small farms was presented in the in the Table 1, average land holding size and labour availability of small farm household in the study area was 1.44 hectare and 360 man-days respectively in both the season. The working capital availability was Rs. 49264 and Rs. 47658 respectively in kharif and rabi season. The sugarcane production is important crop for attaining maximum return by the marginal farms in the study area which was included as minimum area constraint and value was 0.45 ha. number limit on livestock unit was imposed for determining the potential of increasing income and employment.

\section{Resource utilization pattern for small farms}

The linear programming formulation was solved by using computer based MICRO SOFTWARE and results of existing and optimum resource allocation plan of small farms is presented in Table 2. In existing plan area under paddy, jowar, sugarcane, wheat, potato, mustard and oat were $0.35,0.30,1.02$, $0.52,0.42,0.27$ and 0.11 hectare respectively whereas all the area in optimum farm plan covered fewer than three crops viz., sugarcane, potato and oat with $0.45,0.99$ and 0.99 hectare respectively and other crops were not feasible in selected area due to their minor importance in returns. Similarly buffalo and cow were in number of 1.58 and 1.36 respectively in the existing farm plan but due to greater importance of buffalo in planning, it appears 9.24 in numbers in to optimum farm plan.

Further linear programming resulted into a net return of $\square 429103.94$ in optimum farm plan as compared to $\square 320906.10$ in existing farm plan. There is an absolute improvement in net return which was 33.72 per cent higher than the existing farm plan. The land was fully utilized in optimum farm plan, whereas, requirement of labor man-days was 69.59 per cent higher in optimum farm plan than the existing farm plan. Analysis indicates that optimal farm plan seems more feasible because it create more opportunity for employment to the small farm families in the study area. 
Table.1 Matrix of linear programming model for small farms

\begin{tabular}{|c|c|c|c|c|c|c|c|c|c|c|c|c|c|c|}
\hline Crop & $\begin{array}{l}\text { Paddy } \\
(0.30)\end{array}$ & $\begin{array}{l}\text { Jawar } \\
(0.21)\end{array}$ & $\begin{array}{l}\text { Sugarcane } \\
(0.59)\end{array}$ & $\begin{array}{l}\text { Wheat } \\
(0.35)\end{array}$ & $\begin{array}{l}\text { Potato } \\
(0.24)\end{array}$ & $\begin{array}{c}\text { Mustard } \\
(0.13)\end{array}$ & $\begin{array}{l}\text { Oat } \\
(0.05)\end{array}$ & $\begin{array}{c}\text { Buffalo } \\
* \\
(1.3)\end{array}$ & $\begin{array}{r}\text { Cow* } \\
(1.1)\end{array}$ & $\begin{array}{c}\mathrm{KH} \\
\mathrm{L}\end{array}$ & $\begin{array}{l}\mathrm{R} \\
\mathrm{H} \\
\mathrm{L}\end{array}$ & $\mathrm{KB}$ & $\mathrm{RB}$ & $\begin{array}{l}\text { Paddy } \\
(0.30)\end{array}$ \\
\hline Variable & X1 & $\mathbf{X} 2$ & $\mathbf{X 3}$ & X4 & X5 & X6 & $\mathbf{X 7}$ & $\mathbf{X 8}$ & X9 & $\begin{array}{c}\mathrm{X} 1 \\
\mathbf{0}\end{array}$ & $\begin{array}{c}\mathrm{X} 1 \\
1\end{array}$ & $\mathbf{X 1 2}$ & $\mathbf{X 1 3}$ & \\
\hline Kharif Land (ha) & 1 & 1 & 1 & - & - & - & - & - & - & & & & & $\leq 1.23$ \\
\hline Rabi Land (ha) & - & - & 1 & 1 & 1 & 1 & 1 & - & - & - & & & & $\leq 1.23$ \\
\hline $\begin{array}{c}\text { Kahrif Laboure } \\
\text { (man-days) }\end{array}$ & 96 & 38 & 80 & - & - & - & & 30 & 25 & -1 & - & - & & $\leq \mathbf{3 6 0}$ \\
\hline $\begin{array}{l}\text { Rabi Laboure } \\
\text { (man-days) }\end{array}$ & - & - & 70 & 45 & 78 & 31 & 32 & 28 & 23 & - & -1 & - & - & $\leq \mathbf{3 6 0}$ \\
\hline $\begin{array}{c}\text { Kahrif working } \\
\text { capital (Rs.) }\end{array}$ & 32346 & 16421 & 30080 & - & - & - & & 31317 & 26047 & - & - & -1 & - & $\leq 49264$ \\
\hline $\begin{array}{l}\text { Rabi working } \\
\text { capital (Rs.) }\end{array}$ & - & - & 27904 & 27579 & 63007 & 18028 & 18328 & 30610 & 25083 & - & - & - & - & $\leq 47658$ \\
\hline Minimum area (ha) & - & - & - & - & - & - & & & & - & - & - & -1 & $\geq 0.45$ \\
\hline Net Return (Rs.) & 60366 & 40608 & 113326 & 55082 & 75670 & 45556 & 38315 & 37599 & 27588 & - & - & - & - & \\
\hline
\end{tabular}

Table.2 Land allocation, income and employment generation under optimum combination of different enterprises in sugarcane based farming of small farms

\begin{tabular}{|c|c|c|c|c|c|c|c|c|c|c|}
\hline \multirow[t]{2}{*}{ Crop } & \multirow{2}{*}{ 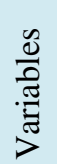 } & \multicolumn{3}{|c|}{ Land Allocation } & \multicolumn{3}{|c|}{ Labour } & \multicolumn{3}{|c|}{ Net Return } \\
\hline & & Existing & Optimum & $\% \Delta$ & Existing & Optimum & $\% \Delta$ & Existing & Optimum & $\% \Delta$ \\
\hline Paddy & $\mathrm{X}_{1}$ & 0.35 & 0 & -100 & 32.9 & 0 & -100 & 21379.4 & 0 & -100 \\
\hline Jowar & $\mathrm{X}_{2}$ & 0.30 & 0 & -100 & 11.40 & 0 & -100 & 12301.5 & 0 & -100 \\
\hline Sugarcane & $\mathrm{X}_{3}$ & 1.02 & 0.45 & -55.88 & 153.00 & 67.50 & -55.88 & 115860.8 & 51115.05 & -55.88 \\
\hline Wheat & $\mathrm{X}_{4}$ & 0.52 & 0 & -100 & 23.92 & 0 & -100 & 28284.88 & 0 & -100 \\
\hline Potato & $\mathrm{X}_{5}$ & 0.42 & 0.99 & 135.71 & 32.34 & 29.70 & 135.71 & 32621.82 & 76894.29 & 135.71 \\
\hline Mustard & $\mathrm{X}_{6}$ & 0.27 & 0 & -100 & 8.37 & 0 & -100 & 13171.41 & 0 & -100 \\
\hline Oat & $\mathrm{X}_{7}$ & 0.11 & 0.99 & 800.00 & 93.22 & 76.23 & 800.00 & 4117.74 & 37059.66 & 800.00 \\
\hline Buffalo & $\mathrm{X}_{8}$ & 1.58 & 9.24 & 484.81 & 65.28 & 545.16 & 484.81 & 57121.74 & 334019.9 & 484.81 \\
\hline Cow & $\mathrm{X}_{9}$ & 1.36 & 0 & -100 & 3.3 & 0 & -100 & 36046.8 & 0 & -100 \\
\hline Total & & & & & 423.73 & 718.59 & 69.59 & 320906.1 & 429103.94* & 33.72 \\
\hline
\end{tabular}

$\% \Delta$ - Percentage change over existing, 


\section{(Appendix - I)}

Optimal value of the objective Function $=429103.95000$

\begin{tabular}{lrrrr} 
Activity & Allocation & Objective & Contribution & Reduced Cost \\
Paddy & $\mathbf{0 . 0 0 0 0 0}$ & $\mathbf{6 1 0 8 4 . 0 0 0 0 0}$ & $\mathbf{0 . 0 0 0 0 0}$ & $\mathbf{2 5 1 0 4 . 6 8 0 0 0}$ \\
Jowar & $\mathbf{0 . 0 0 0 0 0}$ & $\mathbf{4 1 0 0 5 . 0 0 0 0 0}$ & $\mathbf{0 . 0 0 0 0 0}$ & $\mathbf{2 4 7 6 . 8 8 3 0 0}$ \\
Sugarcane & $\mathbf{0 . 4 5 0 0 0}$ & $\mathbf{1 1 3 5 8 9 . 0 0 0 0 0}$ & $\mathbf{5 1 1 1 4 . 9 8 0 0 0}$ & $\mathbf{0 . 0 0 0 0 0}$ \\
Wheat & $\mathbf{0 . 0 0 0 0 0}$ & $\mathbf{5 4 3 9 4 . 0 0 0 0 0}$ & $\mathbf{0 . 0 0 0 0 0}$ & $\mathbf{1 2 8 7 2 . 0 8 0 0 0}$ \\
Potato & $\mathbf{0 . 9 9 0 0 0}$ & $\mathbf{7 7 6 7 1 . 0 0 0 0 0}$ & $\mathbf{7 6 8 9 4 . 3 5 0 0 0}$ & $\mathbf{0 . 0 0 0 0 0}$ \\
Mustard & $\mathbf{0 . 0 0 0 0 0}$ & $\mathbf{4 8 7 8 3 . 0 0 0 0 0}$ & $\mathbf{0 . 0 0 0 0 0}$ & $\mathbf{1 4 2 1 5 . 4 0 0 0 0}$ \\
Oat & $\mathbf{0 . 9 9 0 0 0}$ & $\mathbf{3 7 4 3 4 . 0 0 0 0 0}$ & $\mathbf{3 7 0 5 9 . 6 8 0 0 0}$ & $\mathbf{0 . 0 0 0 0 0}$ \\
Buffalo & $\mathbf{9 . 2 3 9 0 6}$ & $\mathbf{3 6 1 5 3 . 0 0 0 0 0}$ & $\mathbf{3 3 4 0 1 9 . 9 0 0 0 0}$ & $\mathbf{0 . 0 0 0 0 0}$ \\
Cow & $\mathbf{0 . 0 0 0 0 0}$ & $\mathbf{2 6 5 0 5 . 0 0 0 0 0}$ & $\mathbf{0 . 0 0 0 0 0}$ & $\mathbf{2 9 4 7 . 3 0 9 0 0}$ \\
Kharif Hired Labour & $\mathbf{0 . 0 0 0 0 0}$ & $\mathbf{- 2 0 0 . 0 0 0 0 0}$ & $\mathbf{0 . 0 0 0 0 0}$ & $\mathbf{- 5 2 8 . 2 3 5 0 0}$ \\
Rabi Hired Labour & $\mathbf{- 1 . 4 6 5 1 9}$ & $\mathbf{- 2 0 0 . 0 0 0 0 0}$ & $\mathbf{2 9 3 . 0 3 8 2 0}$ & $\mathbf{0 . 0 0 0 0 0}$ \\
Kharif Borrowing & $\mathbf{2 7 5 6 4 7 . 6 0 0 0 0}$ & $\mathbf{- 0 . 1 2 0 0 0}$ & $\mathbf{- 3 3 0 7 7 . 7 1 0 0 0}$ & $\mathbf{0 . 0 0 0 0 0}$ \\
Rabi Borrowing & $\mathbf{3 0 5 1 1 8 . 4 0 0 0 0}$ & $\mathbf{- 0 . 1 2 0 0 0}$ & $\mathbf{- 3 6 6 1 4 . 2 1 0 0 0}$ & $\mathbf{0 . 0 0 0 0 0}$ \\
\hline \multicolumn{2}{r}{} & Objective Function & 429103.94000 &
\end{tabular}

\section{Resources / Constraints}

Kharif land (ha.)

Rabi land (ha.)

Kharif labour(man day)

Rabi labour (man days)

Kahrif working capital (Rs.)

Rabi working capital (Rs.)

Minimum area (ha.)

$\begin{array}{ccc}\text { Type } & & \text { Slack } \\ <= & \mathbf{0 . 0 0 0 0 0} \\ <= & \mathbf{0 . 0 0 0 0 0} \\ <= & \mathbf{0 . 0 0 0 0 0} \\ <= & \mathbf{0 . 0 0 0 0 0} \\ <= & \mathbf{0 . 0 0 0 0 0} \\ <= & \mathbf{0 . 0 0 0 0 0} \\ >= & \mathbf{0 . 0 0 0 0 0}\end{array}$

Utilization

1.44000

1.44000

360.00000

360.00000

49264.00000

47658.00000

0.45000
R.H.S.

1.44000

1.44000

360.00000

360.00000

9264.00000

47658.00000

0.45000
Shadow price

13765.35000

54635.04000

728.23500

200.00000

0.12000

0.12000

32448.48000

\section{Sensitivity Analysis}

$\begin{array}{lrl}\text { Activity } & \text { Objective } & \text { Incoming Variable } \\ \text { Oat } & \mathbf{3 7 4 3 4 . 0 0 0 0} & \text { Jowar } \\ \text { Sugarcane } & \mathbf{1 1 3 5 8 9 . 0 0 0 0} & \\ \text { Potato } & \mathbf{7 7 6 7 1 . 0 0 0 0} & \text { Wheat } \\ \text { Buffalo } & \mathbf{3 6 1 5 3 . 0 0 0 0} & \text { Cow } \\ \text { Rabi Hired Labour } & \mathbf{- 2 0 0 . 0 0 0 0} & \text { Mustard } \\ \text { Kharif Borrowing } & \mathbf{- 0 . 1 2 0 0} & \text { Jowar } \\ \text { Rabi Borrowing } & \mathbf{- 0 . 1 2 0 0} & \text { Mustard } \\ & \mathbf{R . H . S} & \text { Outgoing Variable } \\ \text { Resource/Constraint } & \mathbf{1 . 4 4 0 0} & \text { Rabi Hired Labour } \\ \text { Kharif land (ha.) } & \mathbf{1 . 4 4 0 0} & \text { Potato } \\ \text { Rabi land (ha.) } & \mathbf{3 6 0 . 0 0 0 0} & \text { Kharif Borrowing } \\ \text { Kharif labour(man day) } & \mathbf{3 6 0 . 0 0 0 0} & \text { Rabi Hired Labour } \\ \text { Rabi labour (man day) } & \mathbf{4 9 2 6 4 . 0 0 0 0} & \\ \text { Kahrif working capital } & \mathbf{4 7 6 5 8 . 0 0 0 0} & \\ \text { Rabi working capital } & \mathbf{0 . 4 5 0 0} & \text { Oat } \\ \text { Minimum area (ha.) } & & \end{array}$

\begin{tabular}{|c|c|c|}
\hline Lower Limit & Incoming Variable & Upper Limit \\
\hline 120 & Kharif land (ha.) & 146037.5000 \\
\hline 64798.9200 & & \\
\hline 32525.5400 & Kharif land (ha.) & 50836.0500 \\
\hline-509.0303 & Rabi labour (man day & 0.0000 \\
\hline-0.5214 & Kahrif working capit & 0.0000 \\
\hline-0.4317 & Rabi working capital & 0.0000 \\
\hline Lower Limit & Outgoing Variable & Upper Limit \\
\hline 1.3821 & Buffalo & 11.2950 \\
\hline 0.4500 & Rabi Hired Labour & 1.4590 \\
\hline 85.0741 & Rabi Hired Labour & 361.7365 \\
\hline 358.5348 & & \\
\hline & Kharif Borrowing & 324911.6000 \\
\hline & Rabi Borrowing & 352776.4000 \\
\hline-0.5400 & Rabi Hired Labour & 0.4836 \\
\hline
\end{tabular}


The adoption of improved technology had a much higher impact on increasing farm income. Similarly, the integrated crop and milk production showed a scope for generating employment on small categories of farms. Thus from the optimal plans for small categories of households, it could be inferred that there are significant potentials for income and employment generation in the study area. These could be achieved by making just a few adjustments in the existing farm plans, suggested by the developed optimal farm plans. Adoption of recommended technology even with restricted capital investment resulted in higher net farm income and better utilisation of human labour. With relaxation of capital constraint, more profitability could be generated with more opportunities for human labour employments.

In conclusion, the central point of dispute revolves around the nature of the impact of new farming system on income generation among the farms. The change in cropping pattern, which is still in its transitional stage has lifted agriculture from decades of stagnation to a new threshold of growth and dynamism. The change in farming system has given rise to new hopes and aspiration to the farms regarding the future of agriculture. An empirical study has been done to know the actual impact of sugarcane based farming system on income and farm employment in Meerut district of Uttar Pradesh. In the small farms linear programming model included constraints were land $\leq 1.23$ ha., labour $\leq 360$ days, capital $\leq$ Rs. 111201, and minimum area $\leq 0.45$ ha. In rabi and kharif season. In the further linear programming result for small farms rearing 9.24 buffalo in optimal plan compare to rearing 1.58 buffalo on existing plan that increase in returns which was 33.72 per cent higher than the existing farm plan and labour man days 69.59 per cent higher than the existing plan. The results of the developed response functions revealed that using linear programming model showed for all the seven crops and rearing of livestocks. The model resulted in optimal land allocation in sugarcane based farming system in district Meerut, Uttar Pradesh. The main components, viz., crop and livestock proved complementary to each other. Thus in the farming system of land use, farm products, rearing of livestock and their by-products are better utilized and fetch more income and generate employment.

\section{References}

Anonymous ;Behera, U.K., Jha, K.P. and Mahapatra, I.C. (2004). "Integrated management of available resources of the small and marginal farmers for generation of income and employment in eastern India". Crop Research, 27(1): 83-89.

Anonymous; Behera, U.K. and Mahapatra, I.C. (1999). "Income and employment generation of small and marginal farmers through integrated farming systems". Indian Journal of Agronomy, 44(3): 431-439.

Ansari, M. A., Prakash, N., Baishya, L. K., Punitha, P., Yadav, J. S., Sharma, P. K., Blessa, S. and Ansari, M. H. (2013). "Comparative study on conventional and improved integrated farming systems for sustainable production, income generation and employment opportunity among the tribal farmers in hilly regions of Manipur". Indian Journal of Agricultural Sciences, 83 (7): 765772.

Deoghare, P.R., Sharma, B.M. And Goel, S.K., (1991). "Impact of credit and technology on income and employment of small farms under different farming systems in Karnal district (Haryana)". Agricultural Situation in India, 46 (2): 65-70. 
NCEUS (2008), "A Special Programme for Marginal and Small Farmers", A Report prepared by the National Commission for Enterprises in the Unorganized Sector, NCEUS, New Delh

Parihar and Sinduu (1986). "An factors affecting labour employment on Panjab farms". Punjab agricultural university, Ludhiana.

Sharma A.K. And P. Mehta (1990). "Optimum combination of milch cattle and crops in submountaneous low hills subtropical zone of Himachal Pradesh". Indian Journal of Dairy Science, 43(3): 302-307.

Sharma, G. C. and Gangwar, B. (2000). Economic analysis of sugarcane production in Khadar area of Western U.P.. Bhartiya Krishi Anusandhan Patrika, 15 (1/2): 69-75.

Shinde, N., Patil, B. L., Murthy, C. and Desai, N. R. M. (2009). "Profitability analysis of sugarcane based inter cropping systems in Belgaum district of Karnataka". Karnataka Journal of Agricultural Science, 22 (4): 820-823.

Singh, A.K. and Sharma, J.S. (1988). "Income and employment increasing possibilities under different farming systems on small farms in midwestern region of U.P.”. Agril. Situ. India, 43 (1): 17-23.

Singh, R.B., P. Kumar and T. Headwood (2002), "Smallholder farmers in India: Food Security and Agricultural Policy", FAO, Regional office for Asia and the Pacific, Bangkok.

Singh, S.P., Gangwar, B. and Singh, M.P. (2008). "Economics of sugarcanebased farming system in western Uttar Pradesh". Agricultural Economics Research Review, 21: 109-117.

Tarai, R. K., Sahoo, T. R. and Behera, S. K. (2016) "Integrated farming system for enhancing income, profitability and employment opportunities. International Journal of Farm Sciences, 6 (2): 231-239.

Thapa, G. and R. Gaiha (2011), "Smallholder farming in Asia and the Pacific: Challenges and Opportunities", paper presented at the Conference on new directions for small holder agriculture, 24-25 January 2011, Rome, IFA

\section{How to cite this article:}

Subhash Kumar Jawla, Babu Singh, Teshu Kumar and Rahul Katiyar. 2018. Income and Employment Generation under Optimum Combination of Different Enterprises in Sugarcane Based Farming System for Small Category of Farms in District Meerut of Uttar Pradesh, India. Int.J.Curr.Microbiol.App.Sci. 7(07): 1160-1166. doi: https://doi.org/10.20546/ijcmas.2018.707.140 